\title{
ProDev Participation and Teaching Performance: A Case Study of Two Urban School EFL Teachers in Indonesia
}

\author{
Tono Suwartono ${ }^{1, *}$, Putu Kerti Nitiasih ${ }^{2}$ \\ ${ }^{1}$ Department of English Language Teaching, Universitas Muhammadiyah Purwokerto, Indonesia \\ ${ }^{2}$ Department of English Language Education, Universitas Pendidikan Ganesha Singaraja, Indonesia
}

Received May 8, 2020; Revised May 20, 2020; Accepted June 23, 2020

Copyright $@ 2020$ by authors, all rights reserved. Authors agree that this article remains permanently open access under the terms of the Creative Commons Attribution License 4.0 International License

\begin{abstract}
EFL teachers take the position as front-liners in attempt to promote the nation's human resource quality. Unfortunately, in Indonesia, the competence of EFL teachers remains low. Some teachers take steps to solve this problem. This study aimed to investigate the participation of two urban primary school EFL teachers in professional development and its impact on their teaching performance. Semi-structured interviews with the teachers and colleagues were conducted, documents were collected, and student questionnaires were administered. Data were analyzed using inductive technique, content analysis, and descriptive statistics. The study has shown that the two EFL teachers' participation in professional development was not yet optimal. Indeed, in quantity, their participation was above average. In quality, however, inadequate attention was given primarily to relevance and role taking. With regard to teaching performance, the study has shown that the two teachers' performance was not optimal, either. Their personal and social competences were extremely superior to the pedagogical and professional ones. The latter should have been more demanding in order to attain a better learning process as well as outcome. At last, the study has revealed that despite their urban work environment the two EFL teachers' less quality participation in professional development was believed to have its unsatisfactory impact on their performance in classroom.
\end{abstract}

Keywords Professional Development, Participation, Teaching Performance, EFL Teachers, Case Study

\section{Introduction}

Teachers, including EFL teachers, play a vital role in bringing a generation to the bright future. An educated generation can bring the nation to the level of world competition [1]. Therefore, every teacher should have high professionalism and performance. Unfortunately, the facts have shown that, overall, the competence and quality of EFL teachers in Indonesia remains low [2]. The improvement of teacher's quality is crucial in the domain of education, but it remains a challenge in Indonesia [3]. One thing for sure, for instance, is the fact that of those certified teachers taking Teacher Competence Exam usually only about twenty percent pass it. To solve this problem it is not possible to take actions solely through formal teacher training or education. All efforts should be synergized to boost the EFL teachers' professionalism and sharpen their performance.

Professionalism is defined as the skill and high standards of behavior expected of a professional person [4]. Professionalism is a multi-dimensional structure that reflects one's attitudes and behavior towards their occupation and the achievement of high standards and the expertise of subject matter [5]. According to the national policy in Indonesia, teacher professionalism has something to do with the ability of teachers in conducting their role and function and how they behave at school and in society context [6]. In Indonesia, endeavors by the Government to enhance teacher professional development have become much stronger for the last decade. All models have been tried out in dealing with this issue. Within the national teacher certification program, for example, a few patterns have been implemented and revised, starting from the portfolio model, then short training, to most recently professional teacher education. To the latter itself a few revisions have been made with the inclusion of online course.

An exciting question arises, then. Is it enough with all such programs, including the most updated professional 
teacher education program to generate better professional and qualified EFL teachers? While initially portfolio scheme gained massive negative reactions, there is no guarantee with the recently implemented model the EFL teachers will perform better. Moreover, recently an investigation report has strongly criticized the shortcomings within the EFL teacher education program [7].

An alternative answer to the question above is involvement in professional development-oriented activities, to which EFL teachers might have no limit of time and space. Participation of teachers in such activities as training and workshops, classroom inquiries in action research studies, instructional module writing, student worksheet writing, teaching media development, teacher consultative forum, relevant courses, etc. too many to mention, is promising.

Several studies have exhibited the poor participation of teachers in professional development activities, with no exception of EFL teachers [8]. Many of them have joined workshops, training, and seminars without all their heart. Usually, they have typical reasons of overburden teaching hours or no approval from the school principal. Most teachers in Indonesia spend too much time a week of timetabled teaching, often up to 28 hours per week, with demanding administrative jobs, committee tasks, and diverse extra-curricular activities [9]. In this case, there is a need for a wise communication. Teachers should be aware that teacher professional development is all their needs instead of obligation. On the other hand, wise school authorities know teacher professional development is needed by their teaching staff to sharpen competence and, therefore, they have to support teachers' efforts and facilitate them by providing them with advice and suggestions as to what, where, and when a training is worth joining [10].

One indicator of teachers' professionalism is their performance in classroom. Performance relates to what teachers do in the classroom and how that affects student learning [11]. Thus, teachers' performance is observable. What they do during lessons has impact not only on students' learning process but also on their learning outcome.

According to Article 14 Year 2005 in the Indonesian Constitution, teacher competence covers four types: pedagogical, professional, personal, and social [12]. These four competences are expected to be equally present in every individual teacher on duty. This research was aimed to describe the EFL teachers' participation roles, capacity, and intensity in their professional development activities, describe the EFL teachers' performance in classroom, and examine the qualitative impact of the EFL teachers' participation on their teaching performance.

\section{Materials and Methods}

This descriptive case study research involved two EFL teachers working for primary schools at urban area of Purwokerto, Central Java, Indonesia. Both teachers had been working at different schools - State Junior High School 1 of Purwokerto and State Junior High School 2 of Purwokerto - for eleven years. They were identified as two EFL teachers who actively took activities related with professional development. As many as 182 students at the two schools participated as respondents in the research. They were taught English by the two teachers under investigation. Within this holistic case study, two analysis units were connected while common characteristics were drawn for conclusion [13].

Data on teacher participation in professional development-oriented activities were collected through semi-structured interviews with the school authority (principals and vice-principals) and all teachers of English at both schools, including the ones under investigation. Semi-structured interviews combine both structured and unstructured approaches [14]. An interview guide was prepared and the interviews were recorded. Meanwhile, the main data on participation were collected through documents. Certificates, acknowledgement or appreciation letters, project reports, and others which confirm involvement in professional development activities were gathered. A checklist was needed to organize the documents. In addition, questionnaires - a written collection of self-report questions to be answered by a selected group of research participants [15] were administered to students to elicit data on teacher performance in classroom. Both closed and open questionnaires were used. The closed questionnaires employed a 5 point-Likert-scale and consisted of 22 items.

The interview data on teacher participation in professional development were analyzed using qualitative mode of inductive technique. Content analysis was done to the documents. The Likert scale questionnaire data on teacher performance in classroom were analyzed using descriptive statistics, while investigation of the impact of the EFL teachers' participation in professional development activities on their performance in classroom was approached by using qualitative inductive technique. This data analysis technique was made possible with methodological triangulation involving more than one method to gather data as mentioned earlier [16].

\section{Research Result and Discussion}

In light of the problem being investigated in the present study, the following are the results to be presented. First, concerning participation in professional development, the two EFL teachers selected in this study, Mrs. Marshanda and Mr. Hamdan (written under pseudonyms) were passionate, self-confident, and potential EFL teachers. Among colleagues at work, both of them took professional development-oriented activities or events most actively. 
Mrs. Marshanda, for example, said to have participated in professional development activities because she felt confident enough and indeed needed things of the sort. To her, such activities constitute "supplementary" required to improve achievement. Besides being aware of the potential she had, she acknowledged her weaknesses. Just because of her weaknesses, she decided to participate in professional development activities, as she commented (originally in the native language) on: "Actually I have ideas, opinions, then motivation, and ... creativity, whatever it is. But then, at times, to realize creativity, I am thinking like: is it right?” It is a question which reflects motivation to learn from reliable sources.

The school principal nominated Mrs. Marshanda as the most active English teacher to participate in professional development activities among the three teachers of the same type working at the school. Mrs. Marshanda was also considered to get much involved in the local teachers' consultative forum as a district instructor. Regarding with her service as a district instructor, she was considered frequent to pass on any information to colleagues at work.

In the meanwhile, Mr. Hamdan has shown himself as a self-motivated, self-confident, and good-learner teacher. Like Mrs. Marshanda, he was aware of his weaknesses, especially in the case of ICT. At his work environment, Mr. Hamdan was known as a teacher who actively participated in professional development activities as well as the one who enjoyed sharing knowledge. A friend at work commented below:

Right, I frequently share with Mr. Hamdan.... Since he is the chair of our consultative forum, then automatically, I dig the knowledge from him as well. In many things, so I consult to Mr. Hamdan, for example, when I am making a presentation before other teachers, I talk about it with him in advance. In another case, for example, when I am developing a good lesson plan, I always consult to him how to do it and so on.

Actual data on professional development activities collected in the forms of certificates, letters of appreciation, and project reports, have supported the initial information that the aforementioned two EFL teachers were indeed potential. Within a teaching experience of eleven years at present workplace, Mrs. Marshanda had participated at least eighty professional development activities, or 7.27 times per year, while Mr. Hamdan no less than 67 activities, or 5.7 times per year.

In quantity, this achievement much exceeds that of colleagues at the same workplace. Whereas seen from its quality, participation of the two potential EFL teachers in professional development activities can be reported as follows. So far, Mrs. Marshanda has involved herself four times in activities as teacher mentor and source-person in the regency, and ten times attending provincial and national level academic meetings. In the meanwhile, Mr. Hamdan, within an equal period of time has shown better quality participation. Details of his activities in professional development can be seen in Table 1.

Table 1. Mr. Hamdan's Participation in ProDev Activities

\begin{tabular}{|c|c|c|}
\hline No. & Type & Freq. \\
\hline $\mathbf{1}$ & Instructor in training & 2 \\
\hline $\mathbf{2}$ & Source-person at meetings & 1 \\
\hline $\mathbf{3}$ & Chair of organization & 1 \\
\hline $\mathbf{4}$ & $\begin{array}{c}\text { Member of international teacher exchange } \\
\text { program (Thailand) }\end{array}$ & 1 \\
\hline $\mathbf{5}$ & Author of module & 2 \\
\hline $\mathbf{6}$ & $\begin{array}{c}\text { Participant at provincial and national academic } \\
\text { meetings }\end{array}$ & 5 \\
\hline $\mathbf{7}$ & Researcher in classroom inquiry project & 1 \\
\hline
\end{tabular}

Viewed from the content, majority of the activities were training, workshops, or the like associated with pedagogical competence (e.g. present curriculum and its implementation) and only small portion dealt with field of interest, in this case the English language, e.g. a vocabulary course. Very rare were, for instance, teaching material development and classroom inquiry practice. Worse still, little attention was given to professional competence development-oriented activities.

In regard to performance in classroom, Mrs. Marshanda gained good impression from the students (see Figure 1). As many as ninety-three student respondents gave an average score of 83.43 on closed questionnaires. However, some students did not seem to feel as satisfied as the majority (61\%) did with regard to her performance. As can be seen in Figure 1, approximately one-third of the respondents valued her performance at the level "Good" (60-80 interval).

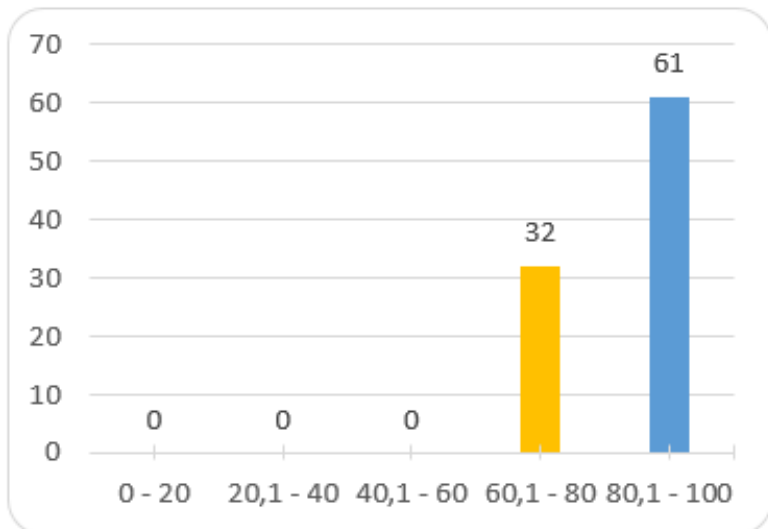

Figure 1. Mrs. Marshanda's performance in the eyes of students

Further analysis has shown that Mrs. Marshanda had personal and social competences favorable to students. Concerning these competences, Mrs. Marshanda was rated excellent in four aspects associated with personal competence, i.e. the teacher was not rude, the teacher cared, the teacher was encouraging, and the teacher was not bad-tempered, and one aspect related to pedagogical competence, i.e. lessons given by the teacher were felt to 
help develop their knowledge and skills of the English language. Result of the open questionnaire supported the data. The open questionnaire has shown that three most liked things of Mrs. Marshanda were: she had a smiling face, she looked attractive, and she taught interestingly. Those all were pride! But, since she was too kind, the students rated her low, instead. One of the open questionnaires supported this, where most of students' feedback was something like they needed a firm and friendly teacher.

While in quality of professional development activities Mr. Hamdan was overall superior to Mrs. Marshanda, his performance in classroom was not rated better than that of Mrs. Marshanda. Students' ratings have shown that Mr. Hamdan gained average score of 71.80 . Figure 2 shows result of the teacher evaluation in more details.

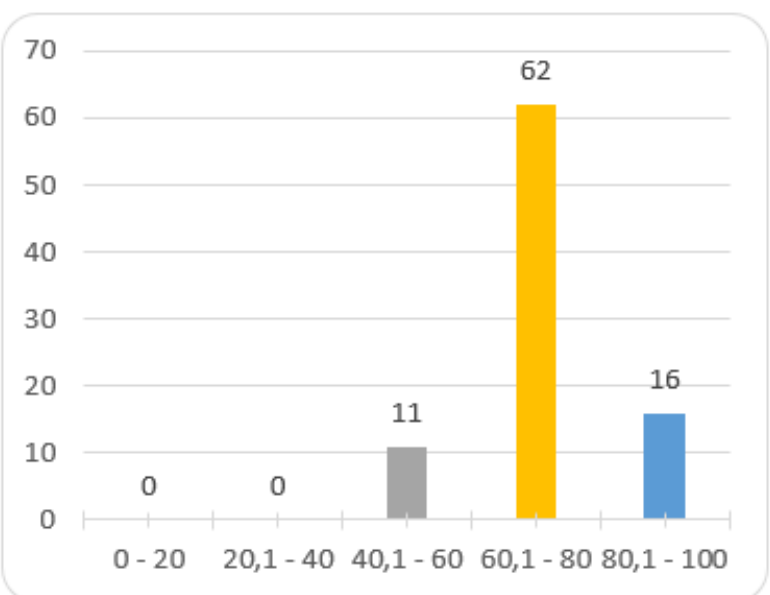

Figure 2. Mr. Hamdan's performance in the eyes of students

As can be seen in Figure 2, some students gave unsatisfactory rating. It is not enough to see only the majority ( $62 \%$ of his students) rated his performance to the level "Good" (60-80 interval) as some eleven percent of them would rather react negatively to his performance, with just level "Fair". Further analysis has shown that seven aspects gained foremost students' ratings: four of personal and social competences, namely: the teacher was not rude, the teacher was not bad-tempered, the teacher cared, and the teacher was encouraging, and one aspect of pedagogical competence, i.e. the lessons he delivered were felt to help develop the language they have been learning, and two of professional competence, i.e. the teacher asked questions during lessons and the teacher answered questions in the class. Result of the open questionnaire supported the data. The open questionnaire has shown that Mr. Hamdan was sympathetic in that he was often absent, he was humorous, and he had a relaxed teaching. An eye-opening finding was that the teacher's absence from the class was something his students like. Quite possible it had something to do with the teacher's unpleasant habit in the class. Data on students' feedback over the teacher's performance highlighted that Mr. Hamdan was often sleepy/fell asleep in classroom, rarely wrote and spoke English during lessons, and was not firm to students.

Since teacher competence, according to the national Constitution shall cover four types, namely pedagogical, professional, personal, and social competences, unless pedagogical and professional competences turn superior over the other two, they should at least appear equal. What is expected from an English teacher relative to performance in classroom if his English as major and teaching methodology are worthless to his students? An English teacher with a good mastery of English and classroom instructional activities is more likely to bring about better learning process and outcome even though he is not kind enough to students than the other way around.

Dominance of personal and social competences over the other competences found in the EFL teachers under investigation has implied the undesirable existing condition. Ideally speaking, teachers of English have strong pedagogical and professional competences. The fact is, based on document of participation in professional development; there has been no sufficient evidence that represented competence development activities by the two EFL teachers, especially the ones that trained professional competence to them.

The two EFL teachers exhibited different orientation in professional development participation. While Mrs. Marshanda reached higher quantity, Mr. Hamdan achieved better quality. Of all their activities of participation, most were dedicated to pedagogical competence development through training or courses. Apart from that, only a small portion of participation took more challenging and active roles, such as main author, speaker, instructor, and classroom researcher. Experts propose activities that require critical, creative, innovative, and collaborative skills in the part of EFL teachers, such as classroom observation and feedback, instructional material development, and action research within Critical Friends Group model to ensure their impact on teacher performance in classroom and student learning outcome [17], [18]. In order for EFL teachers' participation in professional development activities to effectively contribute to their performance in classroom, they will have to take better part in both quantity and quality. Besides, there is a need to keep all four competences balanced.

Professional competence of the two EFL teachers has been the least developed. Presumably, it was effected by low participation in activities that enabled this type of competence to develop. At last, when variables of this study - (1) participation in professional development and (2) performance in classroom - are correlated, it can be said that the two EFL teachers' less quality participation in professional development-oriented activities was believed to have unsatisfactory impact on their performance in classroom.

Result of the present study has been consistent to that of 
previous study in the big city of Yogyakarta [19]. According to their study, professional competence of the EFL teachers under their investigation was rated the lowest from different perspectives: school principals and students. It has shown how professional competence was demanding to acquire. A study has also reported that training on teacher certification program in Indonesia gave nearly no impact on professional competence [20]. Another evidence that supports this matter is the fact that in the national teacher certification program, knowledge examination (most probably associated to professional competence) becomes a monster because it remains the main cause of failure.

\section{Conclusions}

From what we can surmise based on the results and discussion above, substantial conclusions can be drawn from the present study as follows. First, in terms of content proportion in the development of competences and quantity - quality of participation in professional development activities, the two EFL teachers' participation in professional development was not optimum yet. Compared to all their participation, in majority, both EFL teachers took less challenging roles, e.g. as participant rather than presenter or speaker of seminar. Second, in term of performance in classroom, overall, both EFL teachers were not optimum. Both teachers were good in certain competence/s only, especially personal and social competences. Last, the two EFL teachers' less quality participation in professional development-oriented activities was believed to have unsatisfactory impact on their performance in classroom.

Based on the findings presented above, it is suggested that EFL teachers' future participation in professional development activities be improved especially in terms of relevance and quality of participation as well as relative balance of activity content, with emphasis on pedagogical and professional competences. Furthermore, it should be acknowledged that this study has some limitations. First, it is necessary for future researchers to conduct a research of similar type that involves teacher evaluation from different perspectives, not only from students, in order to reduce bias. Second, it is also necessary for future researchers to do a research of this type that includes data on student learning outcome, as impact of teacher performance in classroom. Last but not least, it is necessary for future researchers to hold a research of similar type that applies quantitative approach, in order to see correlation between variables in more measurable way.

\section{REFERENCES}

[1] L. Hakim, B. Tunas, B. Rubini. Evaluation of the
Professionalism of Teachers Accomplishing Certification Program: Evidence from Bekasi City, Indonesia, International Journal of Multidisciplinary Education and Research, Vol. 3, No. 4, 32-35, 2018.

[2] E. I. Sukarni, D. Winarni. Y. T. Nirmayanti. Improving Teachers' Professionalism through Materials Development, Information Technology and Classroom Action Research. TEFLIN Journal, Vol. 20, No. 2, 212-231, 2009. doi: org/10.15639/teflinjournal.v20i2/212-231.

[3] M. S. Panggabean, K. K. Himawan. The Development of Indonesian Teacher Competence Questionnaire. Journal of Educational, Health and Community Psychology, Vol. 5, No. 2, 1-15, 2016.

[4] Suwartono. The Necessity of Synchronizing the EFL Teachers' Perception with their Behavior to Upgrade Professionalism, The $1^{\text {st }}$ Conference on Teaching English as a Foreign Language, Universitas Muhammadiyah Purwokerto, Purwokerto, 31-38, 2009.

[5] E. E. Iroegbu, C. M. Ogbodo. Teacher Professionalism and Nigeria's National Development, IOSR Journal of Research and Method in Education, Vol. 9, No. 3, 40-44, 2019. doi: 10.9790/1959-0903034044

[6] H. Tanang, B. Abu. Teacher Professionalism and Professional Development Practices in South Sulawesi, Indonesia. Journal of Curriculum and Teaching, Vol. 3, No. 2, 25-42, 2014. doi: 10.5430/jct.v3n2p25.

[7] U. Sulistiyo, M. Wiryotinoyo, R, Wulan. Examining an English as a Foreign Language Teacher Education Program (EFLTEP)'s Curriculum: a Case Study in an Indonesian University. European Journal of Educational Research, Vol. 3, Issue 4, 1323-1333, 2019.

[8] A. Hartati. The Teacher Empowerment through MGMP, The 61st TEFLIN International Conference, Universitas Sebelas Maret, Solo, 1231-1235, 2014.

[9] A. Lie, S. M. Tamah, Trianawaty, K. R. Triwidayati, F. Jemadi. English Proficiency Secondary School Teachers in Indonesia, Beyond Words: A Journal on Applied Linguistics and Language Education, Vol. 7, No. 2, 86-100, 2019.doi: 10.33508/bw.v7i2.1950

[10] F. Jalal, D. Supriadi. Educational Reforms in the Context of Local Autonomy, DEPDIKNAS-BAPPENAS-Adicipta Karya Nusa, Yogyakarta, 2001.

[11] B. R. Werang. The Effect of the Principal's Transformational Leadership, Teacher Job Morale, and Job Satisfaction toward Public Elementary School Teacher Performance in Merauke. Cakrawala Pendidikan: Jurnal Ilmiah Pendidikan, Vol. 33, No. 1, 128-137, 2014.doi: 10.21831/cp.v1i1.1869

[12] Kementerian Riset, Teknologi dan Pendidikan Tinggi Republik Indonesia. The Constitution of the Republic of Indonesia Number 14 Year 2005 on Teacher and University Teacher, Kemenrisetdikti RI, Jakarta, 2005.

[13] R. K. Yin. Case Study Research: Designs and Methods (M. Djauzi Mudzakir, Trans.). PT. Raja Grafindo Persada, Jakarta, 2014.

[14] I. Seidman. Interviewing as Qualitative Research: a Guide for Researchers in Education and the Social Sciences. Teachers College Press, Amsterdam, 2019. 
[15] L. R. Gay, G. E. Mills, P. Airasian. Educational Research: Competencies for Analysis and Application, Prentice-Hall, New York, 2012.

[16] N. K. Denzin, M. D. Giardina. Introduction: Qualitative Inquiry and the Conservative Challenge. In Denzin, Giardina (Ed.), Qualitative Inquiry and the Conservative Challenge, Left Coast Press, Walnut Creek, CA, 2006.

[17] D. K. Irmawati. Models of EFL Teachers' Professional Development, The 61st TEFLIN International Conference, Universitas Sebelas Maret, Solo, 1254-1257, 2014.

[18] M. Siddiq. Strategic Factors Affecting the Quality of Primary and Secondary Educations. In Emzir, Chan. (Ed.), The Critical Issues on Educational Policies in the Local Autonomy Era, p. 31, Penerbit Ghalia Indonesia, Bogor, 2010.

[19] R. Munfangati, P. Widodo. Performance of Certified Educator English Teachers in Yogyakarta. Jurnal Ling Tera, Vol. 1, No. 2, 224-236, 2014.

[20] M. Zaim. Comparison in Senior High School English Teacher Performance in the City of Padang Panjang Viewed from Certification Status and Pedagogical and Professional Competences, International Seminar on Languages and Arts (ISLA). FBS Universitas, Padang, 281-295, 2015. 